\title{
Primerjava načel znanstvenega menedžmenta in vitkega proizvajanja
}

\author{
Idriz Selimović* \\ Rotis d.o.o., Smolenja vas 48c, 8000 Novo mesto \\ idrizselimovic@yahoo.com
}

\section{Povzetek:}

Raziskovalno vprašanje (RV): Ali prinašajo načela in dejavniki vitkega proizvajanja bistveno drugačna načela od Taylorjevega znanstvenega menedžmenta?

Namen: Preveriti želimo, ali so načela in dejavniki vitkega proizvajanja dramatično drugačni $v$ primerjavi z znanstvenim menedžmentom.

Metoda: Uporabili smo integrativni pregled strokovne literature za preteklih 40 let (od 1980-2020), v kateri so bila opisana načela in dejavniki znanstvenega menedžmenta in vitkega proizvajanja.

Rezultati: Avtorji preučevanih znanstvenih publikacij zagovarjajo mnenje, da načela in dejavniki vitkega proizvajanja ne prinašajo bistveno drugačnih načela od Taylorjevega znanstvenega menedžmenta. Njegova dela je zato potrebno brati in interpretirati skozi očala družbenoekonomskih in socialnih razlik v času nastanka njegovih del (začetek dvajsetega stoletja) in danes. Organizacija: Pogosto je razlog za uvajanje sprememb v organizacijo napačen, namesto novih organizacijskih prejemov podjetje potrebuje samo dosledno upoštevanje obstoječih načel $v$ kombinaciji z zavzetostjo vodstva. Zavedanje, da organizaciji ne bo pomagal noben organizacijski prejem brez zavzetega vodstva in da ji bo pomagal vsak z zavzetim vodstvom, organizacijam prihrani veliko časa in denarja.

Družba: Napredek in uspeh $\mathrm{v}$ organizaciji se lahko enakovredno doseže $\mathrm{z}$ uporabo načel znanstvenega menedžmenta kot $\mathrm{z}$ načeli vitke organizacije in brez svetovanja zunanjih svetovalcev, pogoj za to je dosledna uporaba načel enega ali drugega pristopa. S tem dosežemo, da se čim več organizacij bolj posveča dejanski implementaciji teh načel v svoje procese, ne glede iz katerega koncepta prihajajo.

Originalnost: Uspeh v organizaciji se lahko enakovredno doseže z uporabo načel znanstvenega menedžmenta kot $\mathrm{z}$ načeli vitke organizacije. Za to je najbolj pomembna zavzetost in predanost vrhnjega menedžmenta izvajanim načelom.

Omejitve/nadaljnje raziskovanje: Anketa o naših ugotovitvah med slovenskim menedžmentom bi smiselno dopolnila naš članek.

Ključne besede: menedžer, načela, sodobni prejemi, Taylor, uspešnost, vitko proizvajanje, znanstveni menedžment.

\section{Uvod}

V sodobnem svetu verjetno ni menedžerja ali lastnika podjetja, ki še ne bi slišal za izraz vitko proizvajanje. Najbolj skeptični se sprašujejo, ali je v konceptu vitkega proizvajanja sploh kaj novega, saj naj bi se vse organizacije na tem svetu vsakodnevno spraševale, kako povečati 
svoje prihodke, kako zniževati stroške z odstranjevanjem izgub iz procesov, kako povečati tržni delež s pridobivanjem novih in z zadrževanjem obstoječih odjemalcev. $Z$ vitkostjo ali brez nje naj bi bilo vse zgoraj našteto smoter vseh organizacij. Hines, Holweg \& Rich (2004, str. 997) navajajo da se je vitkost kot koncept sčasoma razvijala in se bo še naprej. Zaradi tega razvoja se je pojavila velika zmeda glede tega, kaj je vitko in kaj ne - dejstva, ki je jasno opaziti na akademskih in praktičnih konferencah v logistiki in upravljanju operacij. Napačna domneva je da bodo načela vitkega proizvajanja sama po sebi rešila organizacijske težave v določenem podjetju. Tako Bateman, Esain, Massey, Rich in Samuel (2006, str. 15-16) pišejo da $\mathrm{z}$ uporabo načel vitkega proizvajanja, npr. drugega načela »določiti tok vrednosti in odstraniti vse izgube iz tega toka«, ne bomo rešili problema visokih proizvodnih stroškov, če se obstoječi menedžment ne bo lotil njihovega odkrivanja in odstranitve, kakor tudi ne s Taylorjevem načelom iz znanstvenega menedžmenta, ki govori o pretoku materiala skozi proizvodni proces (str. 87, Shop management). Pravzaprav ne obstaja organizacijski koncept, ki bi namesto menedžerjev reševal vsakodnevne izzive v podjetju. Naš namen je opazovati načela in dejavnike znanstvenega menedžmenta skozi paradigmo vitkega proizvajanja, zato bomo iskali odgovor na naše raziskovalno vprašanje, ali prinaša vitko proizvajanje bistveno drugačna načela od Taylorjevega znanstvenega menedžmenta? Menimo, da $\mathrm{v}$ načelih in dejavnikih vitkega proizvajanja ni nič takega, česar ne bi že poznali $v$ znanstvenem menedžmentu z začetka in sredine dvajsetega stoletja.

\section{Pregled literature}

\subsection{Teoretična izhodišča}

Zanimivo je, da kar nekaj sodobnih organizacij še vedno deluje po načelih klasične organizacijske teorije, čeprav vsi oglašamo, da jih je že povozil čas. Tako Evangelopoulos (2011, str. 71) pravi, da je Taylorjevo delo še vedno pomembno in uporabno. Razpravljamo lahko samo o obliki manifestacije njegovih načel. Trditev, da sodobni koncepti proizvajanja, kot je na primer vitko, izhajajo iz Taylorjevega znanstvenega menedžmenta in da jih podpira veliko avtorjev. Bartezzaghi (1999, str. 232) trdi, da vitko proizvodnjo ne bi smeli obravnavati kot prekinitev s prejšnjo paradigmo, temveč kot prenovo in stopnjevanje njenih značilnih lastnosti, kot so rigidna standardizacija, prekomerna delitev dela, opredelitev omejenih vlog, kratko trajanje delovnih ciklov in hierarhičnost organizacije. Ribeiro (2015, str. 77) pravi, da je nadzor nad časom ena glavnih podobnosti med vzorci proizvodnje pri Taylorju in Toyoti. Druga podobnost je ločitev med izvedbo in načrtovanjem. Ta ločitev, ki se je začela pri Taylorju in nadaljevala pri Fordu, je danes še vedno živa pri Toyoti. Vse to nakazuje, da danes živimo v svetu, kjer dosežki treh konceptov živijo skupaj.

$\mathrm{Na}$ drugi strani imamo avtorje, ki imajo kritičen odnos do povezanosti znanstvenega menedžmenta in načel vitkega proizvajanja. Handel (2014. str. 87) meni, da je tradicionalne mehanizme obvladovanja makroekonomskih turbulenc, tuje konkurence, tehnoloških sprememb in spreminjanja okusa potrošnikov povozil čas. Konkurenčne prednosti v novem okolju so hitrejše odločitve, inovativnost in prilagodljivost, ne pa ekonomija obsega in 
kopičenje rezerv notranjih virov. Forza (1996, str. 44) trdi, da je vitki proizvodni sistem filozofija zase in da se razlikuje od znanstvenega menedžmenta $\mathrm{v}$ dveh pomembnih segmentih. Kot prvo, vitka organizacije se nenehno prilagaja tržišču s pomočjo informacij, ki potekajo od tržišča, preko proizvodnega toka, vse do skladišča gotovih izdelkov. Druga velika razlika je ta, da vitko proizvajanje ne vidi več delovne sile kot vir, ki se skuša upreti delovnim nalogam, temveč kot vir, ki želi delati in dajati več. Opazovanje Taylorjevega znanstvenega menedžmenta skozi načela vitke organizacije je možno ob upoštevanju časovne distance med njimi. Taylorjeva načela so $\mathrm{v}$ posameznem časovnem okvirju interpretirana $\mathrm{v}$ skladu $\mathrm{z}$ evolucijo družbeno-ekonomskih, socialnih, političnih in drugih okoliščin, in sicer do trenutka interpretacije. Znanstveni menedžment je dal izhodišča, ki so nam omogočila, da smo razširili svoja razmišljanja $\mathrm{v}$ okvirjih in $\mathrm{z}$ dinamiko razvoja vseh ostalih ved, ki vplivajo na razvoj menedžmenta. Kulesza, Weaver \& Friedman (2017, str. 20) pravijo, da je znanstveni menedžment dal trajen prispevek k razvoju organizacijske misli in da so njegova načela oblikovala sodoben način razmišljanja in življenja.

\subsection{Znanstveni menedžment}

$\mathrm{Na}$ vrhuncu industrijske revolucije, ob koncu devetnajstega stoletja, so lastniki tovarn vse težje nadzirali naraščajoča podjetja. Konflikti z zaposlenimi so naraščali in so bili vse bolj pogosti in intenzivni, včasih so pa prerasli v nasilna soočenja. Vodstvo je iskalo najboljše prakse za preprečevanje konfliktov in spodbujanje produktivnosti. Ko je industrijski inženir Frederick Taylor trdil, da lahko sistematično preuči katero koli delovno mesto in pripravi nabor postopkov, ki bi povečali produktivnost in zadovoljstvo delavcev, je bilo navdušenje s strani lastnikov podjetij razumljivo (Hill \& Van Buren, 2018, str. 266). Peaucelle (2000, str. 454-455) opisuje razmere, ki so vladale v času Taylorja. Taylor se ukvarjal s populacijo, ki sta ji primanjkovala industrijska kultura in tehnično usposabljanje. Delavci, o katerih je Taylor govoril, so bili novi priseljenci v ZDA in so komaj govorili angleško.

V zgodnjem 20. stoletju je bila teorija znanstvenega menedžmenta ena najpogostejših idej in teorij vodenja $\mathrm{v}$ zahodnih industrializiranih državah. Vključuje vrsto znanstvenih metod in teoretičnih podlag za standardizacijo proizvodnih dejavnosti in racionalizacijo proizvodnih organizacij (Grachev \& Rakitsky, 2013, str. 514). Taylor (1967. str. 190) je pri svojem snovanju znanstvenega menedžmenta izhajal iz predpostavke, da je problem slabe učinkovitosti delavcev in nizkih plač možno razrešiti v skupno dobro delavcev in lastnikov. Predlagal je štiri glavna načela:

- znanstveno proučevanje vsakega giba (tudi postopka, operacije ipd.) dela, ki nadomešča staro, »približno - na palec« (rule of thumb), metodo dela;

- sistematično izbiranje, usposabljanje, učenje in razvoj vsakega posameznega delavca,

- iskreno sodelovanje z delavci, da bo delo opravljeno na najboljši možni način,

- managerji naj bodo odgovorni pri odločanju o tem kako naj bo delo opravljeno, medtem ko so delavci odgovorni, da je delo opravljeno. 
Prvo načelo znanstvenega menedžmenta vključuje ločitev delovnega procesa od spretnosti delavcev. Menedžerji prevzemajo breme združevanja vseh tradicionalnih znanj, ki so jih v preteklosti imeli delavci. Nato to znanje razvrstijo, razčlenijo in racionalizirajo $\mathrm{v}$ formule, pravila in zakone, ki so znanstvene narave (Huang, Tung, Lo \& Chou, 2013, str. 79). Simha \& Lemak (2010, str. 235) menita, da so se v času Taylorja vodilni delavci zatekali h grožnjam zaposlenim, da bi povečali proizvodnjo, ker niso imeli potrebnega znanja za izboljšanje metod dela. Poleg tega je Taylor opazil, da so se delavci opirali na stare metode dela, ki jih je vsak delavec odkril sam in jih prenašal na druge, vendar niso bile nujno najučinkovitejši način za izvajanje naloge. Odgovor na takšno stanje stvari je bil Taylorjev sistem (Corwin 2003, str. 139; Su, 2017. str. 105) znanstvenega menedžmenta, ki je uporabljal natančne meritve časa in zapletene enačbe, da bi pri delavcu dosegel »največjo učinkovitost«. Blake \& Moseley (2010, str. 29) detajlno opisujeta postopek proučevanja gibov. V prvem koraku so našli 10 ali 15 delavcev, ki so bili usposobljeni za določeno delo. Naslednji korak znanstvene študije je bila natančna analiza operacij in uporabljenih orodij. Nato so s štoparico merili čas, potreben za vsakega od osnovnih gibov. Na koncu so odpravili vse napačne, počasne in neuporabne gibe, zbrali vse najhitrejše in najboljše gibe in zanje določili točno zaporedje izvajanja. Taylor je bila zelo kritičen do "upravljanja pobude in spodbude" ("management of initiative and incentive"), pri kateri so produktivnost delavcev želeli povečati z grožnjami delavcem, ne pa s tem, da bi poskrbeli za proučevanje in izboljšanje samega dela (Rossler \& Beruvides, 1994, str. 10-11).

Kar se tiče drugega Taylorjevega načela, Turan (2015. str. 1104) pojasnjuje, da je Taylor poudarjal pomembnost zaposlovanja pravega osebja ter ga obravnaval kot pomembno misijo poslovodstva. Delodajalec ne bi smel enostavno odpustiti zaposlenega, ki ga je zaposli in je šel skozi usposabljanje, ki ni bilo zastonj, razen če to res ni potrebno. Locke (1982, str. 17) navaja, da se je Taylor zavzemal za to, da bi za določeno delovno mesto izbrali le moške "prvega razreda" (delavci z visoko sposobnostjo), saj bi bila njihova produktivnost nekajkrat večja kot pri povprečnem moškem. Pri tem omenja primer v tovarni kroglic za ležaje koles, kjer je Sanford E. Thompson uporabil merilo reakcijskega časa za izbiro inšpektorjev za kolesne kroglice. K temu Payne, Youngcourt, \& Watrous (2006, str. 390) dodajajo, da so Taylorjeve ideje o znanstvenem izboru delavcev in pojmu "prvovrstnega človeka" nakazovale, da se zaveda, da je treba delavčeve sposobnosti uskladiti z zahtevami dela, saj se je dejansko zavzemal za usklajenost delavcev $\mathrm{z}$ delovnimi mesti na podlagi njihovih zmogljivosti, kjer bolj kompleksne naloge opravljajo bolj sposobni delavci. Tretje Taylerjovo načelo je nastalo kot rezultat poskusa reševanja ključne težave pri zgodnji uporabi znanstvenega menedžmenta, pomanjkanja izobrazbe med nižjim vodstvenim kadrom in znotraj vrst delavcev. Velik odstotek delavcev v tovarnah so predstavljali nedavni priseljenci, od katerih mnogi niso obvladali angleščine. Zato se je Taylor zalagal, da bi delodajalec vložil več časa in sredstev za izbiro in usposabljanje vsakega zaposlenega, namesto da bi vsak zaposleni, kot je v tistih časih bila navada, bil prepuščen sam sebi (Blake \& Moseley, 2010, str. 29). Da bi organizacija ostala dobičkonosna, je ključnega pomena, da vsak zaposleni nadaljuje opravljanje svojih dolžnosti v skladu z nalogami, ki so zanje določene. Posledica 
tega načela je, da naj bi se delavci nenehno usposabljati in razvijati, da bi bili učinkovitejši pri opravljanju nalog, ki so jim dodeljene (Huang, Tung, Lo \& Chou, 2013, str. 81).

Četrto načelo znanstvenega menedžmenta pojasnjuje, da naj bi bil glavni namen vodstva zagotavljanje čim boljšega počutja vsega osebja. Uspešnost zaposlenega je ključnega pomena za produktivnost delovnega mesta. Na splošno velja, da so interesi zaposlenega in delodajalca nasprotni. Nasprotno, znanstveni menedžment trdi, da so interesi obeh strani enaki. Če delodajalec ne more zagotoviti blaginje zaposlenega, ne more na dolgi rok zagotoviti niti svojega dobrega počutje (Turan, 2015. str. 1103-1104). Taylor je povečal odgovornost poslovodstva pri uspešnosti. V svojih primerih je pozival k 50-50 delitvi dela med delavcem in nadzornikom »prve vrste«. Taylorjevi menedžerji, predhodniki sodobnih strokovnjakov, so bili odgovorni za odstranjevanje ovir, ki so delavcem preprečile doseganje vnaprej načrtovanih rezultatov. V njegovi paradigmi so menedžerji prepoznali svojo vlogo podpiranja uspešnosti in ne zgolj usmerjanja dela drugih. Taylorjev nadzornik je del skupinskega truda, ki dosega želeno produktivno uspešnost (Brogan, 2011, str. 41). Taylor večkrat trdi, da naj bi vodstvo po njegovem sistemu opravilo več nalog, ki so bile prej prepuščene delavcu. Preprosto povedano, vodstvo naj bi pomagalo delavcu, da bi lahko deloval na najboljši možni ravni. To so storili z izdelavo proizvodnih načrtov in dodelitvijo ustreznih nalog primernim delavcem, ki bi lahko $\mathrm{v}$ določenem obdobju opravili več dela in prejeli večjo finančno nagrado (Tadajewski \& Jones, 2012, str. 42).

\subsection{Vitka organizacija}

Koncept vitkega proizvajanja je zaživel v šestdesetih letih dvajsetega stoletja, vendar se ni tako imenoval. Fairris (2002, str. 530) navaja, da so se načela vitke proizvodnje od njegovega nastanka $\mathrm{v}$ japonski proizvodnji $\mathrm{v}$ šestdesetih in sedemdesetih letih prejšnjega stoletja hitro razširila po vsem svetu. Model vitkega proizvajanja je bil v povojnem obdobju eden stebrov visoko produktivnega japonskega gospodarstva. Njegov prenos v druge države je bil manj uspešna. Smatra se, da je Krafcik (1998, str. 41) prvi uporabil izraz »vitkost« v pomenu, kot ga poznamo danes, in sicer v reviji Sloan Management Review, v članku Triumph of Lean Production Systems. James Womack (1990, 1-3 pogl.), ustanovitelj Lean Enterprise Institute in avtor knjig Lean thinking ter The machine that changed the world je opisal Toyotin proizvodni sistem kot »vitko proizvodnjo«. V literaturi se navaja pet glavnih načel vitkega proizvajanja, Unterlechner, Meško Štok in Markič (2009, str. 140):

- natančno opredeljena vrednost posameznega proizvoda (ali storitve)

- z vidika odjemalca;

- prepoznan vrednostni tok (value stream) za posamezni proizvod

- (storitev);

- gladki tokovi materiala in informacij brez prekinitev;

- oskrba se odvija na osnovi pull načela3 odjemalca;

- stremljenje k popolnosti. 
Womack (1990, str. 13); Paez \& all (2004, str. 288) pravijo, da vitko proizvajanje porabi manj vsega v primerjavi z množično proizvodnjo - polovico človeškega truda v tovarni, polovico proizvodnega prostora, polovico naložb v orodje, polovico inženirskih ur za razvoj novega izdelka polovice tima. Liker (2004, str. 20) ugotavlja, da je vitka organizacija nastala iz potrebe po hitrih, fleksibilnih procesih, ki strankam zagotavljajo, kar si želijo, ko želijo, po najvišji kakovosti in ugodnih cenah. Po mnenju Chauhan \& Singh (2012, str. 59) vitki koncept poudarja timsko delo, nenehno usposabljanje in učenje, proizvodnjo po naročilu, množično prilagajanje in zmanjšanje velikosti serij, pretočnost proizvodnih celic, hitre menjave orodja, skupno produktivno vzdrževanje in druge tehnike.

Vitki koncept opisuje moderno organizacijo, ki je podvržena nenehnim spremembam na vseh ravneh, zato Pearce \& Pons (2017, str. 10) podarjata, da je končni cilj vitkega koncepta razvita učeča organizacija. Paez \& all (2004, str. 288) opisujejo glavne značilnosti vitkega proizvajanja z Womackovim nastopom pred komisijo ameriškega kongresa leta 1994. Womack je v svojem nastopu določil tri glavne značilnosti vitke proizvodnje, ki vodijo do boljših rezultatov. Prvič, vitko proizvajanje vključuje novo filozofijo proizvodnje, s poudarkom na zadovoljstvu strank in nenehnem izboljševanju. Drugič, vitko proizvajanje vključuje nove organizacijske tehnike za vodenje razvoja izdelkov, odnosov v dobavni verigi, proizvodnih operacij in usklajevanja celotnega podjetja. Tretjič, vitko proizvajanje uporablja tehnike, kot so pravočasni, istočasni inženiring in sistemi za vodenje zalog (Paez \& all, 2004, str. 288). Vitko organizacijo Jenner (1998, str. 397) vidi kot samoorganizirajoči dinamični sistem, za katerega so raziskave pokazale, da so najbolj eksplicitne, ustvarjalne in prilagodljive strukture, ki se pojavljajo v širokem območju fizikalnega in biološka polja.

\subsection{Znanstveni menedžment $v$ načelih in dejavnikih vitkega proizvajanja}

Peaucelle (2000, str. 453) pravi, da so v današnjih podjetjih še vedno prisotni številni elementi znanstvenega menedžmenta. Pri tem navaja standardizacijo dela kot primer, kjer prihaja do neprijetnega protislovja za tiste, ki napovedujejo propad »taylorizma«. Prav standardizacija dela je eden od elementov vitke organizacije, ki je močno zasidran $\mathrm{v}$ znanstvenem menedžmentu. Peaucelleova se v nadaljevanju sprašuje, ali Ohno, ustanovitelj TPS (Toyota production system) in etablirani Taylorjev učenec, v resnici s TPS-om ne izraža spoštovanja do svojega učitelja.

Liker (2004, str. 158) navaja primer skupne tovarne, ki sta jo v Kaliforniji zgradila Toyota in General Motors: delavci upoštevajo zelo podrobne standardizirane postopke, obstaja veliko vodij skupin in določena hierarhija. Čas, stroški, kakovost in varnost so bili podrobno načrtovani. V NUMMI (kratica za skupno tovarno Toyote in General Motorsa) so imeli prevladujoče značilnosti birokratske in mehanistične organiziranosti, kar sovpada $\mathrm{S}$ prizadevanji Taylorjevega znanstvenega menedžmenta. Adler (1993, str. 17) opisuje skupno tovarno Toyote in General Motorsa (NUMMI) kot »demokratični Taylorizem«. V tovarni NUMMI obstaja jasna standardizacija postopkov, hierarhija, čas izvedbe operacij je določen 
in je vzpostavljen strog nadzor nad stroški in kakovostjo. Torej se s pravom na tem mestu sprašujemo, kaj pa je v Taylorjevem znanstvenem menedžmentu drugače?

Znanstveni menedžment je poznal in uveljavljal sistem zbiranja koristnih predlogov zaposlenih. Unterlechner, Meško Štok in Markič (2009, str.) navajajo da je Taylor svetoval, naj nadrejeni sicer ukazujejo, da uveljavljajo strokovno znanje, a naj podrejenim tudi prisluhnejo, saj imajo izkušnje, zamisli in sposobnosti tudi oni. Ta način razmišljanja nas pripelje do sistema zbiranja koristnih predlogov zaposlenih ki je značilen za vse sodobne organizacije. Seveda je ta sistem danes veliko bolj sofisticiran in razdelan od Taylorjevega, vendar je princip isti: zbrati koristne predloge od tistih ki so v neposrednem stiku s materijo.

Primer dobre prakse, skovanka ki jo poznamo v sodobnem času ima svoje korene pri znanstvenem menedžmentu. Taylorjev primer $\mathrm{z}$ delavcem Schmidtom, ki je s skrbnim načrtovanjem potrebnih gibov za izvedbo operacije nakladanja železa, iz prvotnih 12,5t dosegel $47 \mathrm{t}$ na dan in zmanjšanje potrebnega števila delavk za kontrolo krogličnih ležajev v tovarni koles z 120 na 35 sta dva primera ki to potrjujeta (Brogan, 2011, str. 43-44).

Vijai, Somayaji, Swamy in Aital, (2017, str. 446) pišejo da so po Taylorjevem Znanstvenem menedžmentu vzkliknile nove organizacijske teorije in načela. Taylorjeva načela so na novo ovrednotili in izpopolnili. Nove organizacijske teorije so nastajale kot odraz omejitev prejšnjih. S tem želimo povedati da je trenutno stanje teorije organizacij, ki vključuje tako proizvodne kot storitvene organizacije, rezultat evolucijskega procesa katerem je Taylor dal pomemben prispevek.

\section{Metoda}

V našem članku smo uporabili smernice integrativnega pregleda. Uporabljeno strokovno literaturo smo izbrali po pregledu baz znanstvenih člankov Emerald (www-emerald-com), Jstor (www-jstor-org) in Elsevier (www.elsevier.com). Ključne besedne zveze, ki smo jih uporabili pri iskanju gradiva, so bile: »lean organisation AND scientific management AND similar principle«, »lean production AND traditional plants AND similar principle«, »lean production AND post taylorism«. Predstavljamo jih v tabeli 1.

$\mathrm{V}$ našem članku smo vključili dognanja svetovnih avtorjev s področja znanstvenega menedžmenta in vitkega proizvajanja. Posebno pozornost smo namenili klasikom; Taylor (1967) na področju znanstvenega menedžmenta in Liker (2004) ter Womack (2003) na področju vitkega proizvajanja. Model raziskave smo prikazali na sliki 1. 


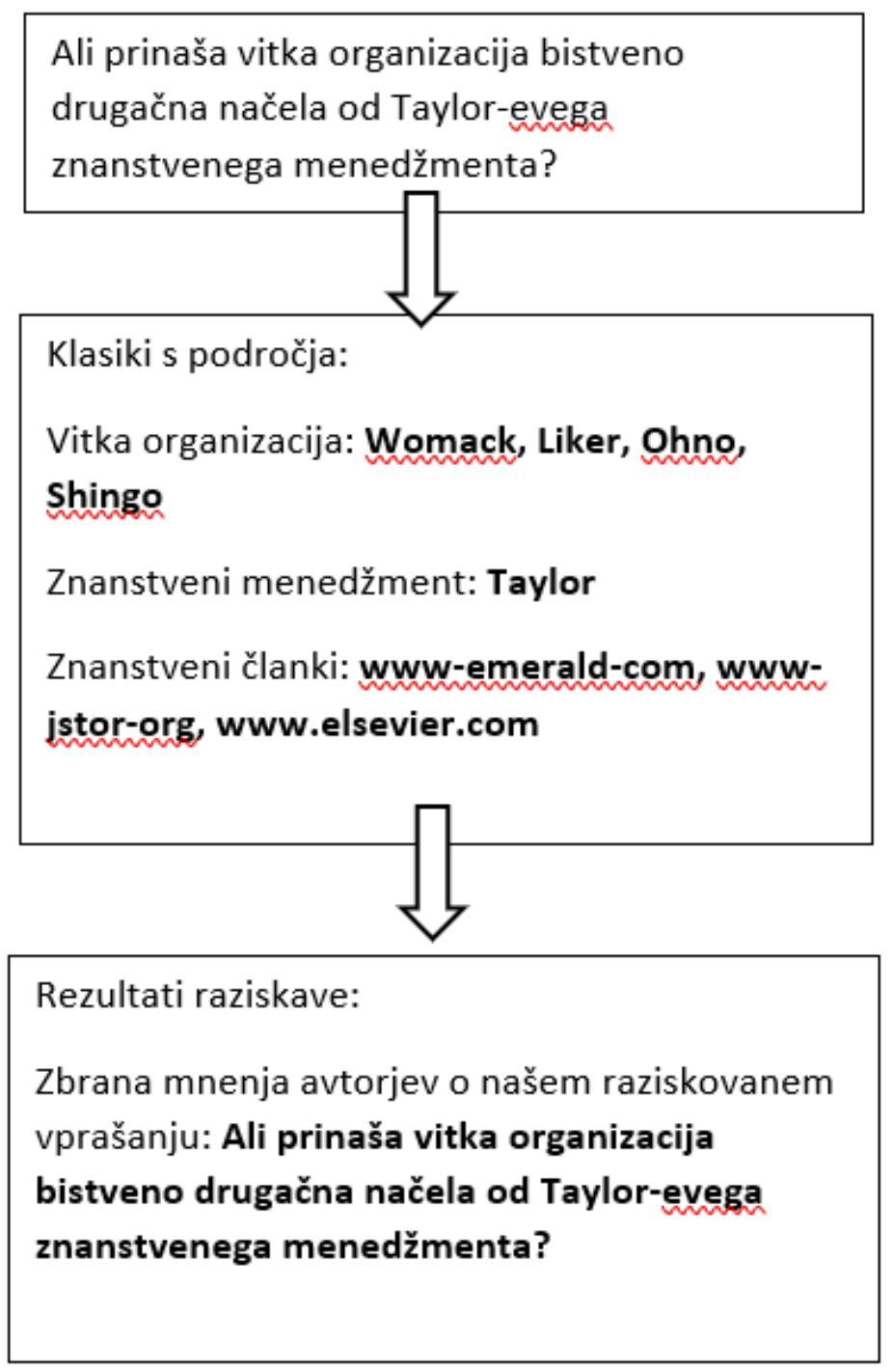

Slika 1. Model raziskave 
Tabela 1. Izidi pregleda literature po ključnih besedah

\begin{tabular}{|c|c|c|c|}
\hline Podatkovna baza & Iskalni niz & Število zadetkov & Izbrani zadetki \\
\hline \multirow{3}{*}{ Emerald } & $\begin{array}{l}\text { lean organisation AND scientific } \\
\text { management AND similar principle }\end{array}$ & 1796 & 10 \\
\hline & $\begin{array}{l}\text { lean production AND traditional plants } \\
\text { AND similar principle }\end{array}$ & 1214 & 4 \\
\hline & lean production AND post taylorism & 102 & 9 \\
\hline \multirow{3}{*}{ Jstor } & $\begin{array}{l}\text { lean organisation AND scientific } \\
\text { management AND similar principle }\end{array}$ & 258 & 7 \\
\hline & $\begin{array}{l}\text { lean production AND traditional plants } \\
\text { AND similar principle }\end{array}$ & 1005 & 9 \\
\hline & lean production AND post taylorism & 181 & 4 \\
\hline \multirow{3}{*}{ Elsevier } & $\begin{array}{l}\text { lean organisation AND scientific } \\
\text { management AND similar principle }\end{array}$ & 1224 & 9 \\
\hline & $\begin{array}{l}\text { lean production AND traditional plants } \\
\text { AND similar principle }\end{array}$ & 626 & 2 \\
\hline & lean production AND post taylorism & 390 & 2 \\
\hline
\end{tabular}

Primarni pogoj o vključenosti literature $\mathrm{v}$ nadaljnje raziskovanje je prisotnost razprave o primerjanju načel znanstvenega menedžmenta in vitkega proizvajanja v raziskovani literaturi. Redukcije preučevanega gradiva smo prikazali na sliki 2. Med zadetki (6796) smo po naslovu gradiva presojali v koliki meri so uporabni za našo raziskavo. Izbrali 321 naslovov, pri katerih smo po prebiranju izvlečka odločali ali jih uvrstimo v nadaljnjo raziskavo. Glede na vsebino izvlečka (abstract) nas je pritegnilo k detajlnem preučevanju 58 bibliografskih enot, za odgovarjanje na naše raziskovalno vprašanje pa smo vključili 31 enot. 

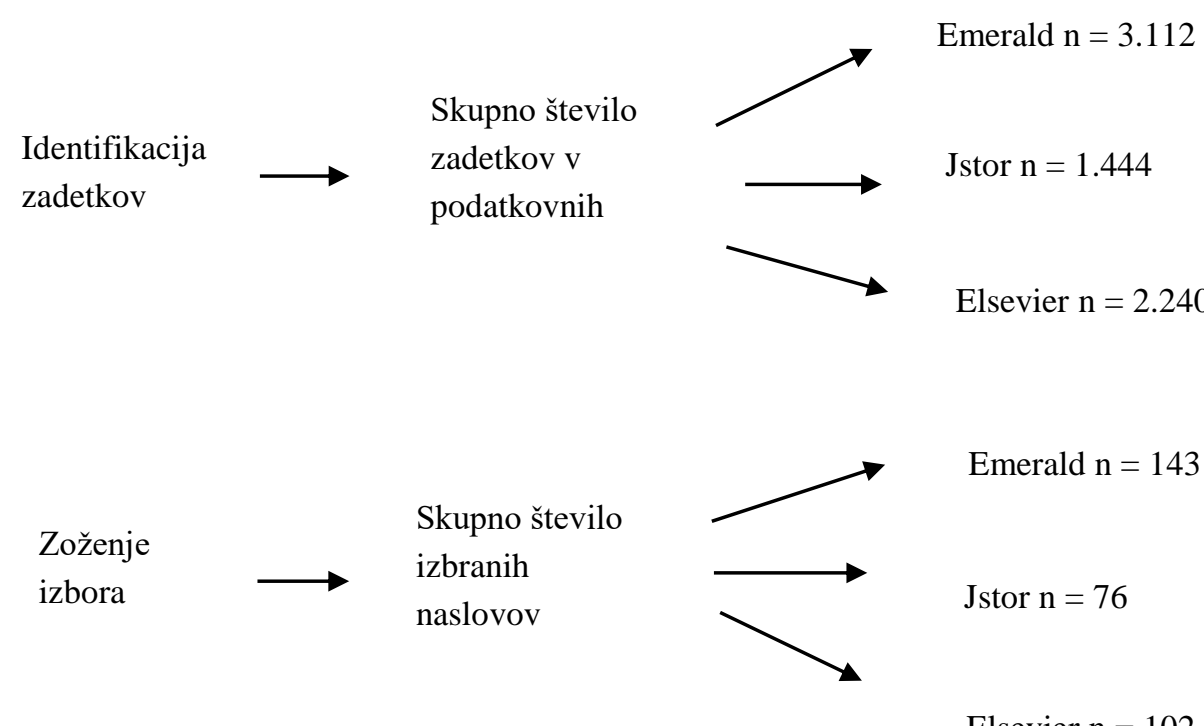

Elsevier $\mathrm{n}=102$

Emerald $n=10$

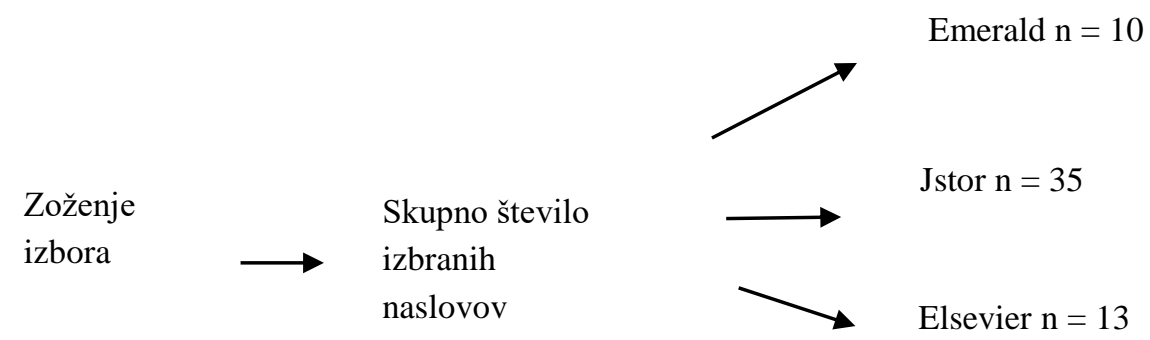

Slika 2. Rezultati pregleda literature po metodologiji Prisma

\section{Rezultati in razprava}

$\mathrm{V}$ tabeli 2 smo predstavili mnenja preučevanih avtorjev. Pri tem smo povzemali njihova razmišljanja $\mathrm{v}$ zvezi $\mathrm{z}$ vitkim proizvajanjem in znanstvenim menedžmentom. $\mathrm{Na}$ podlagi povzetkov smo ocenjevali njihov odnos do našega raziskovalnega vprašanja, ali prinašajo načela in dejavniki vitkega proizvajanja bistveno drugačna načela od Taylorjevega znanstvenega menedžmenta? V prvi koloni smo predstavili avtorja in letnico, v drugi naslov publikacije in v tretji povzetek avtorja glede načel in dejavnikov znanstvenega menedžmenta, ki so uporabljena $\mathrm{v}$ zasnovi vitkega proizvajanja. 
Tabela 2. Povzemanje preučevanih avtorjev

\begin{tabular}{lll}
\hline Avtor, letnica & Naziv publikacije & Mnenje avtorja \\
\hline Peaucelle, J. (2000) & $\begin{array}{l}\text { From Taylorism to } \\
\text { post-Taylorism }\end{array}$ & $\begin{array}{l}\text { Standardizacija dela - Taylorjevo načelo, } \\
\text { močno zasidrano v vitki organizaciji. }\end{array}$ \\
\hline Liker J. K. (2006) & The Toyota way & $\begin{array}{l}\text { V NUMMI (kratica za skupno tovarno } \\
\text { Toyote in General Motorsa) so imeli } \\
\text { prevladujoče značilnosti birokratske in } \\
\text { mehanistične organiziranosti, kar sovpada } \\
\text { s prizadevanji Taylorjevega znanstvenega } \\
\text { menedžmenta. }\end{array}$
\end{tabular}

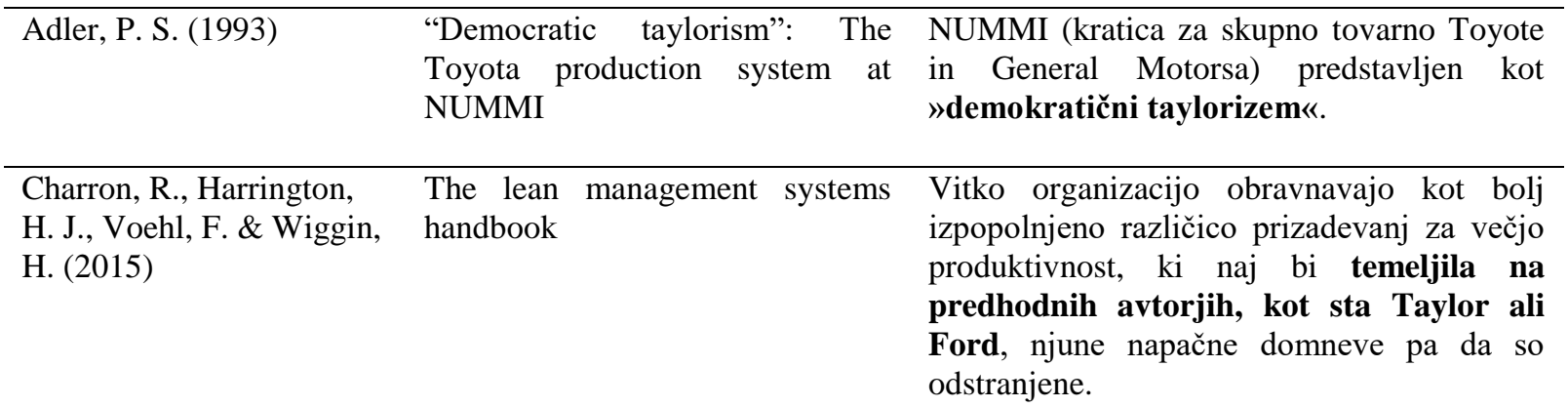

Fujimoto, T. (1999) The Evolution of a Manufacturing Toyotin proizvodni sistem je selektivno System at Toyota sprejel različne elemente Fordovega sistema, jih križal s svojim domiselnim sistemom in izvirnimi idejami. Označuje trditev, da je Toyotin proizvodni sistem čisti izum genialnih japonskih avtomobilskih strokovnjakov, kot mit.

\begin{tabular}{ll}
\hline Bartezzaghi, E. (1999) & The evolution of production \\
models: is a new paradigm \\
emerging?
\end{tabular}

Trdi, da vitke proizvodnje ne bi smeli obravnavati kot prekinitev $s$ prejšnjo paradigmo, temveč kot prenovo in stopnjevanje njenih značilnih lastnosti, kot so rigidna standardizacija, prekomerna delitev dela, opredelitev omejenih vlog, kratko delovnih ciklov in hierarhične organizaci nadalievani

\begin{tabular}{|c|c|c|}
\hline Cattero, B. (1995) & $\begin{array}{l}\text { Nicht nur Verschwendung: über } \\
\text { Redundanz und slack in der } \\
\text { schlanken Produktion }\end{array}$ & $\begin{array}{l}\text { Uporablja izraz »hibridizacije« med } \\
\text { znanstvenim menedžmentom in vitko } \\
\text { organizacijo. }\end{array}$ \\
\hline Forza, C. (1996) & $\begin{array}{l}\text { Work organization in lean } \\
\text { production and traditional plants }\end{array}$ & $\begin{array}{l}\text { Vidi vitki proizvodni sistem kot prilagoditev } \\
\text { znanstvenega menedžmenta } \\
\text { spremenjene tržne razmere. }\end{array}$ \\
\hline
\end{tabular}

Rawlinson, M., \& Wells, Taylorism, Lean Production and Shingo je bil predan spremljevalec P. (1996) the Automotive Industry Taylorjevega dela in uporabe njegovih načel $\mathrm{v}$ industrijskem inženiringu, kar je močno vplivalo na njegovo razmišljanje in organizacijo proizvodnje.

Evangelopoulos, C. C Citing Taylor: Tracing $\quad$ Avtor prikazuje intelektualno območje praks,


»nadaljevanje

$(2011)$
Taylorism's Technical and Sociotechnical Duality through Latent Semantic Analysis idej in filozofij, ki jih je sprožil Taylor, in nakazuje, da je Taylorjevo prvotno delo iz leta 1911 še vedno pomembno.

\begin{tabular}{ll}
\hline Tang, H. (2017) & $\begin{array}{l}\text { 4th International Conference on } \\
\text { Education \& Training, } \\
\text { Management and Humanities } \\
\text { Science }\end{array}$ \\
\hline Ribeiro, A. F. (2015) & Taylorismo, fordismo e toyotismo \\
& \\
\hline $\begin{array}{l}\text { Giannantonio, C. M. \& } \\
\text { Hurley-Hanson, A. E. } \\
\text { (2011) }\end{array}$ & $\begin{array}{l}\text { Frederick Winslow Taylor: } \\
\text { Reflections on the Relevance of } \\
\text { The Principles of Scientific } \\
\text { Management 100 Years Later }\end{array}$
\end{tabular}
Vsako posamezno Taylorjevo načelo in dejavnike znanstvenega menedžmenta pojasnil iz vidika sodobnih organizacijskih zasnov.

\section{Govori o »sintezi«, Taylorizma, Fordizma in} Toyotizma.
Ugotavljata, da so načela in dejavniki znanstvenega menedžmenta prispevali $k$ managerskim praksam v 20. stoletju, vključno s specializacijo nalog, praksami proizvajanja, analizo in oblikovanjem delovnih mest, spodbujanjem sodelavcev, prilagajanjem delavca za delo in količinami proizvajanja ter z nadzorom.

\begin{tabular}{ll}
\hline Kulesza, M. G., Weaver, & Frederick W. Taylor's presence in \\
P., \& Friedman, S. (2011) & $\begin{array}{l}\text { 21st century management } \\
\text { accounting systems and work } \\
\text { process theories. }\end{array}$
\end{tabular}

Pišejo, da načela in dejavniki znanstvenega menedžmenta, ostajajo trajen prispevek k razvoju menedžerske znanosti in stroke. Taylorjeva načela in dejavniki znanstvenega menedžmenta so dobro izhodišče za nadaljnje iskanje učinkovitejšega obvladovanja organizacije.

\begin{tabular}{ll}
\hline Short, J. C. (2011) & The Debate Goes On! A Graphic \\
& Portrayal Of The Sinclair-Taylor \\
& Editorial Dialogue
\end{tabular}

Taylorjeva knjiga o znanstvenem menedžmentu je bila tudi osnova Druckerjevega koncepta menedžmenta s cilji.

\begin{tabular}{ll}
\hline Adams, D. E., Smith T. \& & Taylorism and Operational \\
Urick M. J. (2017) & Excellence Improving on the \\
& "One Best Way"
\end{tabular}

Uporabnosti Taylorjevega pristopa znanstvenega menedžmenta »najboljši način" je zelo očitna, ker je Taylor verjetno mislil "najboljši način ... za zdaj".

Brennan, L.L. (2011) The Scientific Management of Ohno je izhajal iz Fordovega sistema, ko je Information Overload začel z razvojem TPS. Danes so načela in prakse TPS široko uporabljene v proizvodnem $s$ nadalievanie $\mathrm{m} »$ vitke proizvodnje $\ll$.

\begin{tabular}{lll}
\hline Emiliani, M.L. (2006) & $\begin{array}{l}\text { Origins of lean management in } \\
\text { America }\end{array}$ & $\begin{array}{l}\text { Taylorju priznava zelo velik vpliv na razvoj } \\
\text { TPS. }\end{array}$ \\
\hline $\begin{array}{l}\text { Hines, P., Holweg, M., \& } \\
\text { Rich, N. (2004) }\end{array}$ & Learning to evolve & $\begin{array}{l}\text { Taylorjev »najk se nadaljuje } \\
\text { stopnjo »učeče }\end{array}$ \\
\hline Hopp, W. J. (2018) & $\begin{array}{l}\text { Positive lean: merging the science } \\
\text { of efficiency with the psychology } \\
\text { of work }\end{array}$ & $\begin{array}{l}\text { Taiichi Ohno, proizvodni inženir pri Toyoti, } \\
\text { je prevzel Fordove ideje za dvig } \\
\text { učinkovitosti. }\end{array}$ \\
\hline $\begin{array}{l}\text { Hummels, H., \& de Leede, } \\
\text { J. (2000) }\end{array}$ & $\begin{array}{l}\text { Teamwork and Morality: } \\
\text { Comparing Lean Production and } \\
\text { Sociotechnology }\end{array}$ & $\begin{array}{l}\text { Vitka proizvajanje je prilagoditev } \\
\text { Taylorjevega znanstvenega menedžmentu } \\
\text { novemu globalnemu, raznovrstnemu, } \\
\text { fleksibilnemu in visoko konkurenčnemu }\end{array}$ \\
\hline
\end{tabular}




\begin{tabular}{lll}
\hline Parks, C. M. (2003) & $\begin{array}{l}\text { The bare necessities of lean: 10 } \\
\text { things your lean guru may not tell } \\
\text { you about making just-in-time } \\
\text { work }\end{array}$ & $\begin{array}{l}\text { Navodila za delo v vitki organizaciji } \\
\text { izhajajo iz Taylorjevega znanstvenega } \\
\text { menedžmenta. }\end{array}$ \\
\hline Parkes, A. (2015) & $\begin{array}{l}\text { Lean Management Genesis. } \\
\text { Management, }\end{array}$ & $\begin{array}{l}\text { Ponuja dokaze, da so se Toyoda in Ohno } \\
\text { pri razvoju TPS zgledovala po Fordu. }\end{array}$ \\
\hline $\begin{array}{l}\text { Rask, K., \& Johansson, J. } \\
\text { (2008) }\end{array}$ & $\begin{array}{l}\text { Similarities and differences } \\
\text { between lean production, } \\
\text { Tayloristic and socio-technical } \\
\text { systems revealed in the } \\
\text { methodology characteristics map }\end{array}$ & $\begin{array}{l}\text { Osredotočenost na standardizacijo in } \\
\text { podrobna delovna navodila uporabi, da } \\
\text { pokaže, da znanstveni menedžment ima } \\
\text { pomemben vpliv v vitkih proizvodnih } \\
\text { sistemih. }\end{array}$ \\
\hline Turan, H. (2015) & $\begin{array}{l}\text { Taylor's "Scientific Management } \\
\text { Principles": Contemporary Issues } \\
\text { in Personnel Selection Period }\end{array}$ & $\begin{array}{l}\text { Govori o skladnosti Taylorjevih spoznanj in } \\
\text { tehnik s sodobnim upravljanjem ter prikazuje } \\
\text { prispevek Taylorja k vodenju človeških } \\
\text { virov v procesu izbire kadrov. }\end{array}$ \\
& $\begin{array}{ll}\text { The Centennial of Frederick W. } \\
\text { Taylor's The Principles of } \\
\text { Scientific Management: A }\end{array}$ & $\begin{array}{l}\text { Ideje znanstvenega menedžmenta ostajajo } \\
\text { trajen prispevek organizacijski misli. }\end{array}$ \\
\hline Wren, D.A. (2011) & &
\end{tabular}
Scientific Management: A Retrospective Commentary

\begin{tabular}{lll}
\hline Vijai, J. P., Somayaji, G. & Relevance of F.W. Taylor's & Na primeru standardni operativni postopek \\
S. R., Swamy, R. J. R., \& & principles to modern shop-floor & (SOP), ki se razvije in izvaja za vsak element \\
Aital, P. (2017) & practices. Benchmarking & dela operaterja, dokazujejo preživetje \\
& & Taylorjevih načel v sodobnih obratih.
\end{tabular}

\begin{tabular}{lll}
\hline $\begin{array}{l}\text { Blake, A. M., \& Moseley, } \\
\text { J. L. (2010) }\end{array}$ & $\begin{array}{l}\text { One hundred years afterThe } \\
\text { Principles of Scientific } \\
\text { Management: Frederick Taylor's } \\
\text { life and impact on the field of } \\
\text { human performance technology }\end{array}$ & $\begin{array}{l}\text { Sistematične študije časa in analiza } \\
\text { izvajanja operacij so še vedno aktualne v } \\
\text { sodobnih organizacijah in so trajni prispevek } \\
\text { industrializirani družbi. }\end{array}$ \\
\hline Dalcher, D. (2017) & $\begin{array}{l}\text { What has Taylor ever done for } \\
\text { us? Scientific and humane } \\
\text { management reconsidered }\end{array}$ & Prva moderna knjiga o menedžmentu. \\
\hline Arlbjørn \& Freytag (2013) & $\begin{array}{l}\text { Evidence of lean: a review of } \\
\text { international peer reviewed } \\
\text { journal articles. }\end{array}$ & $\begin{array}{l}\text { Vitka organizacija ima korene v } \\
\text { Taylorjevem znanstvenem menedžmentu. }\end{array}$ \\
\hline $\begin{array}{l}\text { Spear, S. and Bowen, } \\
\text { H.K. (1999) }\end{array}$ & $\begin{array}{l}\text { Decoding the DNA of the Toyota } \\
\text { production system }\end{array}$ & $\begin{array}{l}\text { Vitka organizacija ima korene v } \\
\text { Taylorjevem znanstvenem menedžmentu. }\end{array}$ \\
& &
\end{tabular}

$\mathrm{Na}$ podlagi preučevanih člankov je odgovor na naše raziskovalno vprašanje A $\iota$ prinašajo načela in dejavniki vitkega proizvajanja, bistveno drugačna načela od Taylorjevega znanstvenega menedžmenta? naslednji: načela in dejavniki vitkega proizvajanja ne prinašajo bistveno drugačnih načel od Taylorjevega znanstvenega menedžmenta. Povzemanja avtorjev smo pregledno prikazali v tabeli 1 . V raziskavi smo 
obravnavali samo tiste avtorje, ki se strinjajo, da načela in dejavniki vitkega proizvajanja izhajajo iz znanstvenega menedžmenta.

Preučevani avtorji se strinjajo, da načela in dejavniki vitkega proizvajanja izhajajo iz znanstvenega menedžmenta, le da različni avtorji omenjajo različna načela in dejavnike, ki so vitko proizvajanje prevzeli iz znanstvenega menedžmenta. Tako avtorji omenjajo standardizacijo, delitev dela na manjše operacije, študijo časa, vitko organizacijo kot preslikani znanstveni menedžment, kjer so odstranjene napačne domneve, odlične metode za izbiro kadrov, najboljši način (one best way) kot predhodnico učeče se organizacije ter da so načela in dejavniki vitkega proizvajanja hibrid znanstvenega menedžmenta in njegova prilagoditev novim tržnim razmeram.

S svojimi nazori in razmišljanji so teoretiki organizacije na začetku 20. stoletja pomembno vplivali na takratno družbo in bili njena vodilna sila ki je usmerjala smer razvoja družbe. $\mathrm{V}$ bistvu se je takrat začela tendenca ki se je potem skozi čas, vse do danes razvijala; vodilni management je postajal poseben družbeni sloj, s svojimi cilji, hotenji. Ti cilji so močno usmerjali družbeno-ekonomske razmere v Taylorjevem času in danes. Seveda da lahko govorimo o smiselnosti in pravičnosti tih ciljev v širšem kontekstu od področja managementa in organizacije, vendar tako kot na začetku 20. stoletja in kasneje $\mathrm{v}$ nadaljevanju so tvorci organizacijskih teorij načelno skrbeli da njihove teorije oplemenitijo in povečajo učinkovitost organizacijskih procesov. Vsak od njih pa je imel pred sabo drugačne izzive v obliki drugačnih družbeno socialnih razmer, zakonodaje na področju delavskih pravic, pismenosti prebivalstva, drugačnih razmer na prodajnih trgih in še kaj. Menimo da bi Taylor v podobnih razmerah kot jih imamo v sodobnem svetu svoj znanstveni menedžment postavil podobno temu čemu danes pravimo načela vitkega proizvajanja.

\section{Zaključek}

Naša raziskave je imela namen ugotoviti, ali prinašajo načela in dejavniki vitkega proizvajanja, bistveno drugačna načela od Taylorjevega znanstvenega menedžmenta? V empiričnem delu raziskave smo uporabili smernice integrativnega pregleda. Uporabljeno strokovno literaturo smo izbrali po pregledu baz znanstvenih člankov Emerald (wwwemerald-com), Jstor (www-jstor-org) in Elsevier (www.elsevier.com). Ključne besedne zveze, ki smo jih uporabili pri iskanju gradiva, so bile: lean organisation AND scientific management AND similar principle, lean production AND traditional plants AND similar principle, lean production AND post taylorism. Med zadetki (6796) smo po naslovu gradiva presojali v koliki meri so uporabni za našo raziskavo. Izbrali 321 naslovov, pri katerih smo po prebiranju izvlečka odločali ali jih uvrstimo v nadaljnjo raziskavo. Glede na vsebino izvlečka (abstract) nas je pritegnilo k detajlnem preučevanju 58 bibliografskih enot, za odgovarjanje na naše raziskovalno vprašanje pa smo vključili 31 enot. Ugotovili smo, da se preučevani avtorji strinjajo, da načela in dejavniki vitkega proizvajanja izhajajo iz znanstvenega menedžmenta, 
le da različni avtorji omenjajo različna načela in dejavnike, ki jih je vitko proizvajanje prevzelo iz znanstvenega menedžmenta. Na podlagi preučevanih člankov je odgovor na naše raziskovalno vprašanje: načela in dejavniki vitkega proizvajanja ne prinašajo bistveno drugačna načela od Taylorjevega znanstvenega menedžmenta.

Z našim člankom želimo spodbuditi menedžerje $v$ Sloveniji in širše k dodatnem razmisleku preden se lotijo načrtovanja uvedbe novitet $\mathrm{z}$ organizacijskega področja. S preučevanjem dejavnikov in načel znanstvenega menedžmenta in vitkega proizvajanja smo zbrali in predstavili te dejavnike in načela. To lahko pomaga sodobnim menedžerjem pri njihovih vsakodnevnih odločitvah. Vedno si lahko zastavijo vprašanje ali je potrebno uvajati dejavnik vitkega proizvajanja npr. 5S, samo zaradi tega ker je to moderno, ali pa je čisto dovolj izvajati čiščenje in vzdrževanje delovnega mesta, tako kot ga je priporočal Taylor $\mathrm{v}$ svojem znanstvenem menedžmentu. To je naš glavni prispevek menedžerski znanosti in stroki.

V naši raziskavi smo se omejili na tri javno dostopne baze znanstvenih člankov Emerald, Elsevier in Jstor. Raziskavo smo usmerili samo na proizvodno funkcijo, kot eno od temeljnih funkcij vsake gospodarske družbe.

V Sloveniji nismo zasledili podobne raziskave ki bi primerjala načela znanstvenega menedžmenta in vitkega proizvajanja ter temeljila na preučevanju dostopnih baz znanstvenih člankov. Zanimivo bi bilo narediti primerljivo raziskavo ki bi temeljila na preučevanju drugih baz znanstvenih člankov. Možna smer nadaljevanja naše raziskave bi vsekakor bila primerjava načel in dejavnikov znanstvenega menedžmenta in vitkega proizvajanja $\mathrm{v}$ praksi, kjer bi lahko ocenjevali in primerjali uspešnost enih ali drugih načel in dejavnikov ter faktorje, ki imajo na to vpliv.

\section{Reference}

1. Adams, D. E., Smith T. \& Urick M. J. (2017). Taylorism and Operational Excellence Improving on the "One Best Way". Journal of Leadership and Management, 9(10), 7-21.

2. Adler, P. S. (1993). "Democratic taylorism": the toyota production system at NUMMI. Pridobljeno na: https://www.researchgate.net/profile/Paul_Adler/publication

3. Bartezzaghi, E. (1999). The evolution of production models: is a new paradigm emerging? International Journal of Operations \& Production Management, 19(2), 229-250. doi:10.1108/01443579910247446

4. Bateman, N., Esain, A., Massey, L., Rich, N., \& Samuel. D. (2006). Lean Evolution:Lessons from the Workplace. New York: Cambridge Univesitiy Press.

5. Blake, A. M., \& Moseley, J. L. (2010). One hundred years afterThe Principles of Scientific Management: Frederick Taylor's life and impact on the field of human performance technology. Performance Improvement, 49(4), 27-34. doi:10.1002/pfi.20141

6. Brennan, L.L. (2011). The Scientific Management of Information Overload. Journal of Business and Management, 17(1), 121-134. 
7. Brogan, J. W. (2011). Exonerating Frederick Taylor: after 100 years, mythology sometimes overshadows a master's teachings. Industrial Engineer, 43(11), 41-45.

8. Cattero, B. (1995). Nicht nur Verschwendung: über Redundanz und slack in der schlanken Produktion. In M. Birke, B. Hurrle, G. Hurrle, \& V. Mertens (Hrsg.) Pridobljeno na: https://www.ssoar.info/ssoar/bitstream/handle/document/42972/ssoar-1995-catteroNicht_nur_Verschwendung_uber.pdf?sequence $=1$

9. Charron, R., Harrington, H. J., Voehl, F., \& Wiggin, H. (2015). The lean management systems handbook. Boca Ration: Taylor \& Francis Group.

10. Chauhan, G., \& Singh, T. P. (2012). Measuring parameters of lean manufacturing realization. Measuring Business Excellence, 16(3), 57-71. doi:10.1108/13683041211257411

11. Corbacioglu S. (2017). Influence Of Taylorism On Deming's Quality Management. Sarajevo Journal of Social Sciences Inquiry. 2 (2) 77-78. doi: 10.21533/isjss.v2i2.85

12. Corwin, S. (2003). Picturing Efficiency: Precisionism, Scientific Management, and the Effacement of Labor. Representations, 84(1), 139-165. doi:10.1525/rep.2003.84.1.139

13. Dalcher, D. (2017). What has Taylor ever done for us? Scientific and humane management reconsidered. PM World Journal, 4(4), 1-11.

14. Emiliani, M. L. (2006). Origins of lean management in America. Journal of Management History, 12(2), 167-184. doi:10.1108/13552520610654069

15. Evangelopoulos, N. (2011). Citing Taylor: Tracing Taylorism's Technical and Sociotechnical Duality through Latent Semantic Analysis. Journal of Business \& Management, 17(1), 57-72.

16. Fairris, D., \& Tohyama, H. (2002). Productive Efficiency and the Lean Production System in Japan and the United States. Economic and Industrial Democracy, 23(4), 529-554. doi: 10.1177/0143831X02234004

17. Forza, C. (1996). Work organization in lean production and traditional plants. International Journal of Operations \& Production Management, 16(2), 42-62. doi:10.1108/01443579610109839

18. Fujimoto, T. (1999). The Evolution of a Manufacturing System at Toyota. Oxford: Oxford University Press

19. Grachev, M., \& Rakitsky, B. (2013). Historic horizons of Frederick Taylor's scientific management. Journal of Management History, 19(4), 512-527. doi:10.1108/jmh-05-2012-0043

20. Giannantonio C. M. \& Hurley-Hanson A. E. (2011) Frederick Winslow Taylor: Reflections on the Relevance of The Principles of Scientific Management 100 Years Later. Journal of Business \& Management, 17(1), 7-10.

21. Handel M. J. (2014). Theories of lean management: An empirical evaluation. Social Science Research, 44 86-102. doi: 10.1016/j.ssresearch.2013.10.009

22. Hill, V., \& Van Buren, H. (2018). Taylor Won: The Triumph of Scientific Management and Its Meaning for Business and Society. Corporate Social Responsibility, 265-294. doi:10.1108/s2514175920180000002007

23. Hines, P., Rich, N., \& Esain, A. (1999). Value stream mapping. International Journal, 6(1), 60-77. doi:10.1108/14635779910258157

24. Hines, P., Holweg, M., \& Rich, N. (2004). Learning to evolve. International Journal of Operations \& Production Management, 24(10), 994-1011. doi:10.1108/01443570410558049

25. Hopp, W. J. (2018). Positive lean: merging the science of efficiency with the psychology of work. International Journal of Production Research, 56(1-2), 398-413. doi:10.1080/00207543.2017.1387301

26. Huang, K. P., Tung, J., Lo, S. C., \& Chou, M. J. (2013). A review and critical analysis of the principles of scientific management. The international journal of organizational innovation, 5(4), $1-233$.

27. Hummels, H., \& de Leede, J. (2000). Teamwork and Morality: Comparing Lean Production and Sociotechnology. Journal of Business Ethics, 26(1), 75-88. doi:10.1023/a:1006242516664

28. Jenner, R. (1998). Dissipative enterprises, chaos, and the principles of lean organizations. Omega, 26(3), 397-407. doi:10.1016/s0305-0483(97)00067-4 
29. Krafcik, J. F., 1988. The triumph of the lean production system. Sloan Management Review 30(1), $41-52$.

30. Kulesza, M. G., Weaver, P., \& Friedman, S. (2011). Frederick W. Taylor's presence in 21st century management accounting systems and work process theories. Journal of Business \& Management, 17(1) 105-119.

31. Liker J. K. (2006). The Toyota way. New york: McGraw-Hill

32. Liker J. K. (2004). The Toyota way. 14 Management Principles from the World s Greatest. New york: McGraw-Hill

33. Locke, E. A. (1982). The Ideas of Frederick W. Taylor: An Evaluation. The Academy of Management Review, 7(1), 14-24.

34. Paez, O., Dewees, J., Genaidy, A., Tuncel, S., Karwowski, W., \& Zurada, J. (2004). The lean manufacturing enterprise: An emerging sociotechnological system integration. Human Factors and Ergonomics in Manufacturing, 14(3), 285-306. doi:10.1002/hfm.10067

35. Payne, S. C., Youngcourt, S. S., \& Watrous, K. M. (2006). Portrayals of F. W. Taylor across textbooks. Journal of Management History, 12(4), 385-407. doi:10.1108/17511340610692752

36. Parkes, A. (2015). Lean Management Genesis. Management, 19(2), 106-121. doi:10.1515/manment-2015-0017

37. Parks, C. M. (2003). The bare necessities of lean: 10 things your lean guru may not tell you about making just-in-time work. Industrial Engineer, 35(8), 1-39.

38. Pearce, A. D., \& Pons, D. J. (2018). Defining Lean Change-Framing Lean Implementation in Organizational Development. International Journal of Business and Management, 12(4) 10-22. doi: 10.5539/ijbm.v12n4p10

39. Peaucelle, J. (2000). From Taylorism to post-Taylorism. Journal of Organizational Change Management, 13(5), 452-467. doi:10.1108/09534810010377426

40. Rask, K., \& Johansson, J. (2008). Similarities and differences between lean production, Tayloristic and socio-technical systems revealed in the methodology characteristics map. Flexible Automation and Intelligent Manufacturing, 995-1001

41. Rawlinson, M., \& Wells, P. (1996). Taylorism, Lean Production and the Automotive Industry. Asia Pacific Business Review, 2(4), 189-204. doi:10.1080/13602389600000026

42. Ribeiro, A. F. (2015). Taylorismo, fordismo e toyotismo. (Taylorism, Fordism and Toyotism) Lutas Sociais, 19(35), 65-79.

43. Rossler, P., \& Beruvidis, M. (1994). Management theory déjà vu? scientific and total quality management. EMJ - Engineering Management Journal, 6(2), 6-15. doi: $10.1080 / 10429247.1994 .11414780$

44. Short J. C. (2011). The Debate Goes On! A Graphic Portrayal Of The Sinclair-Taylor Editorial Dialogue. Journal of Business \& Management 17(1) 43-56.

45. Spear, S., \& Bowen, H.K. (1999), "Decoding the DNA of the Toyota production system". Harvard Business Review, Vol. 77(5) 97-106.

46. Simha, A., \& Lemak, D. (2010). The value of original source readings in management education: The case of Frederick Winslow Taylor. Journal of Management History, 16(2), 233-252. doi: $10.1108 / 17511341011030129$

47. Su, Y. (2017). Taylor Scientific Management Theory Carding and Significance of Organization Management. Social Sciences, 6(4), 102-107. doi: 10.11648/j.ss.20170604.12

48. Arlbjørn, J.S., \& Freytag, P.V. (2013). Evidence of lean: a review of international peer reviewed journal articles. European Business Review, 25(2), 174-205.

49. Tadajewski, M., \& Jones, D. G. B. (2012). Scientific marketing management and the emergence of the ethical marketing concept. Journal of Marketing Management, 28(1-2), 37-61. doi:10.1080/0267257x.2011.619072

50. Tang, H. (2017). The Implications of Taylorism, Contingency Theory, Behavioral Management Theory and Systems Theory on Organization Management in the Globalization Era: A Comparative and Critical Review. 4th International Conference on Education \& Training, 
Management and Humanities Science (ETMHS 2018). str. 119-122, doi: 10.23977/etmhs.2018.29027

51. Taylor, F. W. (1967) Upravljanje pogonom (Shop management). Beograd: Izdavačko preduzeće Rad.

52. Taylor, F. W. (1967) Naučno upravljanje (Scientific Management). Beograd: Izdavačko preduzeće Rad.

53. Turan, H. (2015). Taylor's "Scientific Management Principles": Contemporary Issues in Personnel Selection Period. Journal of Economics, Business and Management, 3(11), 1102-1105. doi: 10.7763/joebm.2015.v3.342

54. Vijai, J. P., Somayaji, G. S. R., Swamy, R. J. R., \& Aital, P. (2017). Relevance of F.W. Taylor's principles to modern shop-floor practices. Benchmarking. International Journal, 24(2), 445-466. doi:10.1108/bij-02-2015-0019

55. Womack, J. P., Jones, D., T., \& Roos D. (1990). The Machine that changed the World. New York: Rawson Associates.

56. Wren, D. A., \& Bedeian, A. G. (2004). The Taylorization of Lenin: rhetoric or reality? International Journal of Social Economics, 31(3), 287-299. doi:10.1108/03068290410518265

57. Unterlechner,M., Meško Štok, Z., \& Markič, M.(2009). Inoviranje, kakovost in Lean Six Sigma v proizvodnem procesu. Koper: Fakulteta za management.

Idriz Selimović je magistriral na Fakulteti za organizacijske študije FOŠ v Novem mestu s področja modeliranja organizacijskih sprememb. Trideset let deluje $\mathrm{v}$ gospodarstvu na različnih zadolžitvah. Zaposlen je v podjetju Rotis d.o.o. kot pomočnik direktorja proizvodnje.

\section{Abstract: \\ Comparison of the Principles of Scientific Management and Lean Manufacturing}

Research Question (RQ): Do the principles and factors of lean manufacturing bring fundamentally different principles from Taylor's scientific management?

Purpose: We want to check whether the principles and factors of lean manufacturing are dramatically different compared to scientific management.

Method: We used an integrative review of the professional literature for the past 40 years (19802020 ) in which the principles and factors of scientific management and lean manufacturing were described.

Results: The authors of the studied scientific publications defend the opinion that the principles and factors of lean production do not bring significantly different principles from Taylor's scientific management. For this, his works need to be read and interpreted through the glasses of socio-economic and social differences at the time of the creation of his works (early twentieth century) and today.

Organization: Often the reason for introducing changes in the organization is wrong, instead of new organizational receipts, the company only needs to strictly adhere to existing principles combined with the commitment of management. Awareness that no organizational reception will help an organization without committed leadership and that anyone with committed leadership will help it saves organizations a lot of time and money..

Society: Progress and success in the organization can be achieved equally by applying the principles of scientific management as by the principles of lean organization and without the 
advice of external consultants, the condition for this is the consistent application of the principles of one or the other approach. In this way, we achieve that as many organizations as possible are committed to the actual implementation of these principles in their processes, regardless of the concept from which they come..

Originality: Success in an organization can be achieved by applying the principles of scientific management on an equal footing with the principles of lean organization and without the advice of external consultants. The most important thing for this is the commitment and commitment of top management to the implemented principles.

Limitations/Future Research: A survey on our findings among Slovenian management would sensibly complement our article.

Keywords: manager, principles, modern receipts, Taylor, performance, lean manufacturing, scientific management.

Copyright(c) Idriz SELIMOVIĆ

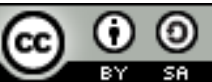

Creative Commons License

This work is licensed under a Creative Commons Attribution-ShareAlike 4.0 International License. 